\title{
Aluminium and calcium lake pigments of Lac natural dye
}

\author{
Ampa Jimtaisong ${ }^{\circledR *}$ \\ ${ }^{1}$ School of Cosmetic Science, Mae Fah Luang University, Chiang Rai 57100, Thailand
}

\begin{abstract}
This work presents the physicochemical properties of the prepared lac lakes. The study revealed the stability, cytotoxicity and use of lac lake pigment as a cosmetic colorant. SEM, XRD and DSC were used to study the characteristics of the lac lakes.. The color stability of lac dye and its lakes was investigated at ambient temperature and at $45^{\circ} \mathrm{C}$, in sunlight,fluorescent light and darkness, for 3 months. Cytotoxicity on human dermal skin fibroblast cell lines was tested using MTT assay and the use of the lakes as a colorant in lip color product was studied. Different metal salts resulted in lac lakes of different shades and appearance. SEM, XRD and DSC results indicated that the morphology and structure of lac dye were changed after reacting with metal salts which support the coordination of metal ion with lac dye. The lac lakes were not cytotoxic to human dermal skin fibroblast cells $(0.78-100 \mu \mathrm{g} / \mathrm{mL})$. Lac lakes exhibited less alteration of color shade over acidic and basic conditions when compared with the lac dye itself. Additionally, the lake pigments displayed better color stability than lac dye and produced an orange-brown shade of lip color product. The results suggest that lac lake pigments have good potential for use as cosmetic colorant.
\end{abstract}

Keywords: Laccaic acids. Natural lac dye. Lake pigment.Cosmetics.

\section{INTRODUCTION}

Lac natural dye is a red colorant obtained from the insects Laccifera lacca and Kerria lacca (Kongkachuichay, Shitangkoon, Chinwongamorn, 2002b). Lac dye is a mixture of at least five closely related laccaic acids derived from 2-phenylantraquinone. These five acids are laccaic acids A, B, C, D and E (Figure 1), with a major amount of laccaic acid A (71-96\%) and B (20\%) (Erwin, 2008). Lac dye was reported to possess medicinal properties for treatment of boils, burns and controlling blood flow after birth (Basu, Haq, Chaudhuri, 1996). It also exhibited strong in vitro antioxidant activity (Jimtaisong, Janthadee, Nakrit, 2013). With its bright and attractive red color together with its non-toxicity to human health; it has been used as material for food coloring (Divya et al., 2011; Oka et al., 1998; Hua, Hong, Zhongue, 2003; Hong et al., 2011).

Laccaic acids are water soluble dyes with an antraquinoid type structure (Burwood et al., 1965; 1976). The water soluble dye can be converted into an insoluble pigment by making it into a lake pigment. This pigment exhibited improved staining ability and good resistance to heat, light and oxygen (Taeko, Keiko, 1980; Cosentino, Fontenele, Del Mastro, 2005). Lake pigments are produced by the precipitation of a particular dye with metal salt (Vera de Rosso, Mercadante, 2009; Anstead, 1959). Carmine is an example of a red lake pigment produced through the reaction of natural cochineal (carminic acid) and aluminium salt, and it is currently used in foods and cosmetics (Schmidt-Jacobsen, Frandsen, 2010). Carminic acid is an antraquinone type dye with a bright red shade, and is highly resistant to light-induced-fading (Cosentino, Fontenele, Del Mastro, 2005; Schmidt-Jacobsen, Frandsen, 2009). We have previously studied the preparation and characterization of the aluminium and calcium lake pigment of lac natural dye (Wongwad et al., 2012). This paper deals with the physicochemical properties of the lac lake pigments. Scanning electron microscopy (SEM), X-ray diffraction (XRD) and differential scanning calorimetry (DSC) analyses are revealed. Color stability, cytotoxicity and the application of lake pigment in color makeup were also studied.

\footnotetext{
*Correspondence: A. Jimtaisong. School of Cosmetic Science, Mae Fah Luang University, Chiang Rai 57100, Thailand. Tel.: +66 53916843; Fax: +66 5391 6831. E-mail: ampa@mfu.ac.th
} 
<smiles>[R]c1ccc(O)c(-c2c(O)c(O)c3c(c2O)C(=O)c2c(cc(O)c(C(=O)O)c2C(=O)O)C3=O)c1</smiles>

Laccaic acid $\mathrm{A}: \mathrm{R}=\mathrm{CH}_{2} \mathrm{CH}_{2} \mathrm{NHCOCH}_{3}$ Laccaic acid $\mathrm{B}: \mathrm{R}=\mathrm{CH}_{2} \mathrm{CH}_{2} \mathrm{OH}$

Laccaic acid $\mathrm{C}: \mathrm{R}=\mathrm{CH}_{2} \mathrm{CH}\left(\mathrm{NH}_{2}\right) \mathrm{COOH}$

Laccaic acid $\mathrm{E}: \mathrm{R}=\mathrm{CH}_{2} \mathrm{CH}_{2} \mathrm{NH}_{2}$<smiles>Cc1c(C(=O)O)c(O)cc2c1C(=O)c1c(O)cc(O)cc1C2=O</smiles>

Laccaic acid D

FIGURE 1 - Chemical structures of laccaic acids.

\section{MATERIAL AND METHODS}

\section{Material}

Deionized (DI) water (Milli-Q/Millipore, USA) was used as the solvent for all preparations. Sodium hydroxide $(\mathrm{NaOH})$ came from UNILAB, Philippines. Calcium carbonate $\left(\mathrm{CaCO}_{3}\right)$ was obtained from Chemex, USA. Calcium acetate monohydrate $\left(\mathrm{Ca}\left(\mathrm{CH}_{3} \mathrm{COO}\right)_{2} \cdot \mathrm{H}_{2} \mathrm{O}\right)$ originated at $\mathrm{POCH}$ SA, Poland. Aluminium potassium sulphate or alum $\left(\mathrm{AlK}\left(\mathrm{SO}_{4}\right)_{2} \cdot 12 \mathrm{H}_{2} \mathrm{O}\right)$ and aluminium chloride $\left(\mathrm{AlCl}_{3}\right)$ were procured from Ajax Fine Chem, Australia. All chemicals are of technical grade. Lac natural dye (industrial grade) was purchased from Creasia Mill Co., Ltd., Thailand. All chemicals were used as received.

\section{Methods}

\section{Preparation of lake pigments}

The lake pigments were prepared in accordance with the previous study (Wongwad et al., 2012). Lac natural dye $(2 \mathrm{~g})$ was dissolved in $50 \mathrm{~mL}$ of DI water and the $\mathrm{pH}$ of lac dye solution was adjusted to $3.5 \pm 0.1 \mathrm{using} 1 \% \mathrm{w} / \mathrm{v}$ $\mathrm{NaOH}$. Each metal salt solution $(10 \mathrm{~mL}, 10 \% \mathrm{w} / \mathrm{v})$, i.e., aluminium potassium sulphate (alum), aluminium chloride, calcium acetate monohydrate, and calcium carbonate, was added into the reaction mixture. Reactions of aluminium and calcium salts were prepared under different conditions (Wongwad et al., 2012). The aluminium lake was prepared by heating at $100{ }^{\circ} \mathrm{C}$ for $2 \mathrm{~h}$, while the calcium lake was prepared at ambient temperature for $30 \mathrm{~min}$. The reaction mixture was filtered using filter paper at room temperature and incubated at $45^{\circ} \mathrm{C}$ overnight. In addition, a mixedmetal salt lake pigment was prepared by using aluminium potassium sulphate and calcium acetate monohydrate.

\section{Scanning electron microscopy (SEM)}

The surface morphology of lac dye and its lake pigments was investigated by scanning electron microscopy (SEM, JEOL/JSM- 5910 LV, Japan). The surfaces of the samples were coated with gold as a conductive material.

\section{Differential scanning calorimetry (DSC)}

This analysis required placing a sample in an aluminium dish before testing. The DSC measurements were performed on a Differential scanning calorimeter (METTLER TOLEDO/DSC822e, Germany) with a thermal analyzer. Samples (1.0-3.0 mg) were placed and sealed in aluminium pans, before being heated under a nitrogen flow $(50 \mathrm{~mL} / \mathrm{min})$ at a scanning rate of $10^{\circ} \mathrm{C} / \mathrm{min}$ from 35 to $250^{\circ} \mathrm{C}$. An empty aluminium pan was used as a reference (control).

\section{$X$-Ray diffraction (XRD)}

Powder XRD patterns were obtained at room temperature using a XRD diffractometer (PANalytical/ X'Pert Pro MPD, The Netherlands), with a $\mathrm{Cu} \mathrm{K} \alpha$ target tube, NaI detector, variable slits, a 0.050 step size, operated at a voltage of $30 \mathrm{kV}, 15 \mathrm{~mA}$ current, at 2 theta $(2 \theta) / \mathrm{min}$ scanning speed, and scanning angles ranging from 0 to $80^{\circ}$.

\section{MTT cytotoxicity test}

The MTT assay was a modified version of conventional direct and indirect contact tests conformed to the published standard method (BS-EN30993-5 and ISO10993-5). The human dermal skin fibroblast cells were seeded in a 96-well plate at a density of 6,000 cells/well and incubated for $48 \mathrm{~h}$. The samples $(6.25-100 \mu \mathrm{g} / \mathrm{mL})$ were added to the cells and incubated for $24 \mathrm{~h}$. The test samples were removed from the cell cultures and the cells 
were reincubated for a further $24 \mathrm{~h}$ in a fresh medium and then tested with MTT assay (Plumb, Milroy, Kaye, 1989). Next, $50 \mu$ of MTT in PBS at $5 \mathrm{mg} / \mathrm{mL}$ was added to the medium in each well and the cells were incubated for $4 \mathrm{~h}$. The medium and MTT were then aspirated from the wells, and formazan solubilized with $200 \mu \mathrm{L}$ of DMSO and $25 \mu \mathrm{L}$ of Sorensen's Glycine buffer, at a pH of 10.5. The optical density was read with a microplate reader (Molecular Devices) at a wavelength of $570 \mathrm{~nm}$. The average of the 4 wells was used to determine the mean of each point. The experiments were carried out 3 times in order to obtain the values and standard deviation. The data were analyzed with the SoftMax Program (Molecular Devices) to determine the $\mathrm{IC}_{50}$ for each toxin sample. A dose-response curve was derived from 8 concentrations in the test range using 4 wells per concentration. Toxic compounds are expressed as the concentration of each sample required to kill $50 \%\left(\mathrm{IC}_{50}\right)$ of the cells compared to the control.

\section{Effects of $\mathrm{pH}$ on color stability}

$5 \%$ of lac natural dye and its lake pigments were mixed with DI water and the $\mathrm{pH}$ of the mixture was measured. The $\mathrm{pH}$ value of each mixture was then adjusted in the range of $1-13$ with the addition of $1 \% \mathrm{NaOH}$ or $1 \%$ $\mathrm{HCl}$. The color was visually observed and photographed.

\section{Effects of storage on color stability}

Lac natural dye and its lake pigments were prepared as a powder dispersion (30\% lac dye or its lake pigments in talc) and oil dispersion (45\% powder in castor oil). The stability was tested under 5 storage conditions: at ambient temperature, sunlight exposure, fluorescent exposure, darkness, and at $45^{\circ} \mathrm{C}$. The color change was measured for 3 months using a Chromameter (Minolta CR-400, Japan).

\section{Application of lac lakes in lip color product}

Lac natural dye and its lake pigments were used to adjust the color shade in lip color preparation. All waxes are melted at $75-80{ }^{\circ} \mathrm{C}$. Oils were mixed with colorants and heated to approximately $75-80{ }^{\circ} \mathrm{C}$. The oils and waxes were then mixed homogeneously and the mixture was poured into a container to examine its characteristics (color, smoothness, texture).

\section{RESULTS AND DISCUSSION}

\section{Preparation of lake pigments}

Lake pigments used in foods and cosmetics are usually prepared in the form of aluminium or calcium lakes because they have been approved for safety and non- toxicity (Plumb, Milroy, Kaye, 1989). Aluminium-calcium lakes have been generated for use in foods such as yogurt fruit preparation and beverages, as well as in cosmetics (Smith, Wagner, 1991). Therefore, aluminium potassium sulphate or alum $\left(\mathrm{AlK}\left(\mathrm{SO}_{4}\right)_{2} .12 \mathrm{H}_{2} \mathrm{O}\right)$, aluminium chloride $\left(\mathrm{AlCl}_{3}\right)$, calcium carbonate $\left(\mathrm{CaCO}_{3}\right)$, and calcium acetate monohydrate $\left(\mathrm{Ca}\left(\mathrm{CH}_{3} \mathrm{COO}\right)_{2} \cdot \mathrm{H}_{2} \mathrm{O}\right)$ were selected for lake preparation. The lac natural dye was used without any purification. The resulting Al-lake complexes were dark-red solids. The alum lake possessed a more brilliant, glossy and homogeneous texture than that of Al chloride. The Ca-lake complexes possessed dark-violet precipitates, and the $\mathrm{Ca}$ acetate lake was more glossy and homogeneous than that of $\mathrm{Ca}$ carbonate. It may noted that lake pigments prepared using alum and $\mathrm{Ca}$ acetate were relatively high in yield, showed smooth and fine textures and are more preferable for cosmetics (Wongwad et al., 2012). Thus, these salts were selected for the preparation of the mixedmetal lake complex. Treatments of the dye solution with alum and $\mathrm{Ca}$ acetate salt were performed by either adding the alum first, followed by adding $\mathrm{Ca}$ acetate, or vice versa. The results presented that when alum was added first, the Al-Ca lake,it obtained fine, glossy, dark-red precipitates. When $\mathrm{Ca}$ acetate was added first, the Ca-Al lake, it was less glossy, producing a darker color, Figure 2.

\section{Characterization}

\section{Scanning electron microscopy (SEM)}

Lac natural dye (1) showed fine platelet features as can be seen in Figure 3. SEM analysis of the alum lake (B) and the Al chloride lake $(\mathbf{C})$ revealed that the surface appearances of both lakes are grouped in the grape fruit shape. The Ca carbonate (D) and Ca acetate lakes (E) possessed particularly rough and uneven shapes and the $\mathrm{CaCO}_{3}$ lake seems to be bigger than that of $\mathrm{Ca}$ acetate. SEM analysis of the mixed-metal salts lakes, $(\mathbf{F})$ and $(\mathbf{G})$, showed different surface morphology. The Al-Ca lake has a relatively rounded and smaller shape, while the $\mathrm{Ca}-\mathrm{Al}$ lake possessed configurations that varied in both size and shape. SEM results indicated that the complexation between lac dye and metal salts changed the lac dye features and may suggest that this occurs due to the interaction between metal salts and lac dye.

\section{Differential scanning calorimetry (DSC)}

The DSC thermograms of lac dye and its lakes are shown in Figure 4. Lac dye (1) exhibited two positions of endothermic peaks; this may be due to containing more than one major compound (Erwin, 2008). When lac dye was prepared as lake pigments by using various metal 


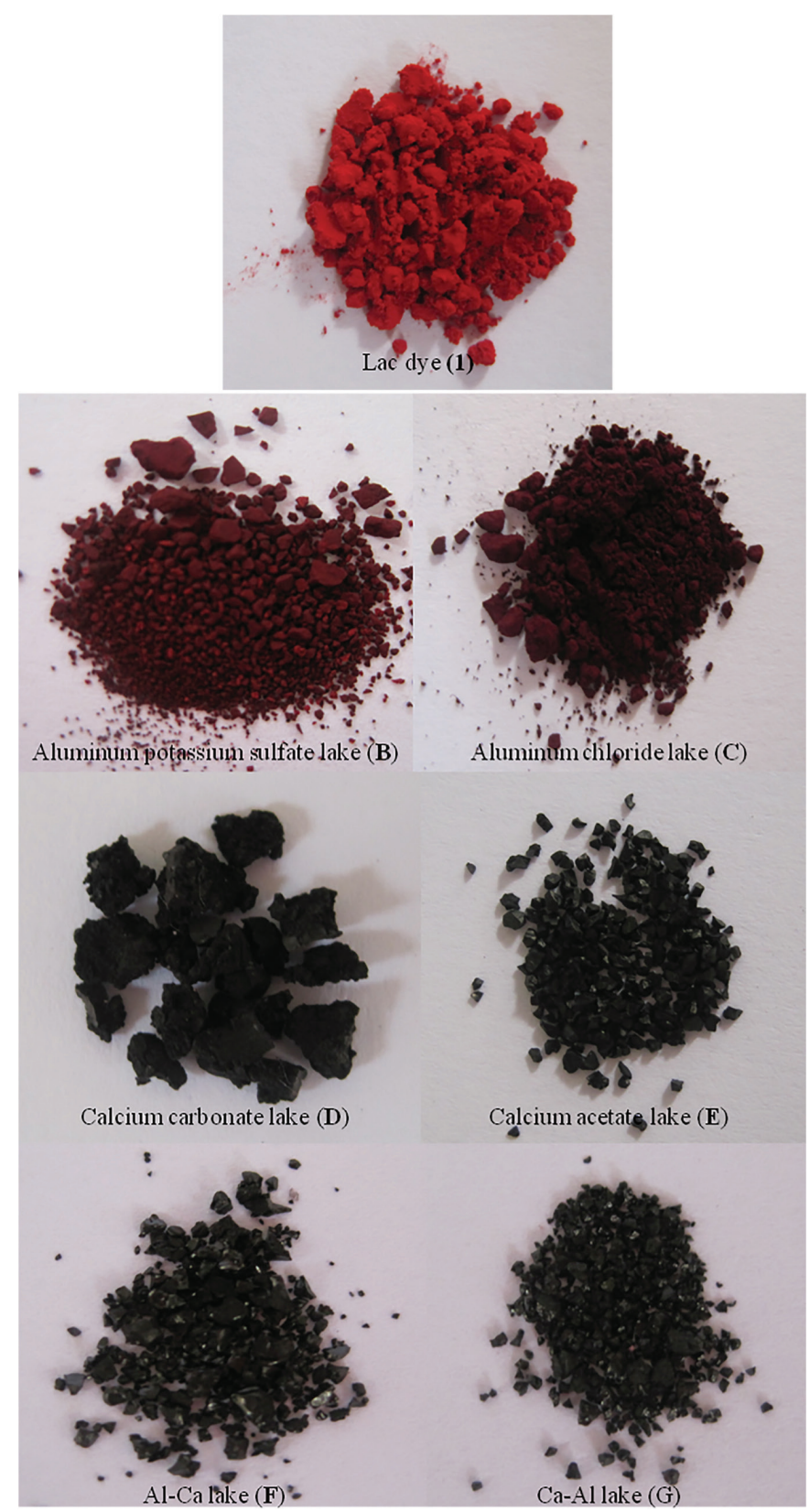

FIGURE 2 - Precipitates of metal lake complexes.

salts, the shift in the endothermic peak minima to lower temperatures was observed in metal complexes $(\mathbf{B}, \mathbf{C}, \mathbf{D}$, $\mathbf{E}, \mathbf{F}$ and $\mathbf{G})$. The DSC results may indicate that the metal ions might loosely coordinate with the $\mathrm{OH}$ group of lac dye (Wongsooksin et al., 2008; Abdelhedi et al., 2008).

\section{$X$-Ray diffraction (XRD)}

The XRD pattern of lac natural dye (1) exhibited its characteristic crystalline peaks at around $5^{\circ}, 13.5^{\circ} 15.5^{\circ}$, $17.5^{\circ}, 23.5^{\circ}, 25^{\circ}$, and $26.5^{\circ}$. For Al lakes, the crystalline peaks showed at $5^{\circ}, 13.5^{\circ}, 21^{\circ}$ and $\sim 27-28^{\circ}$ for the alum lake (B) and only a broad and weak peak at $27-28^{\circ}$ for the Al chloride lake (C). The XRD pattern of the Ca acetate lake (E) showed a strong crystalline peak at $28^{\circ}$ while the Ca carbonate lake (D) displayed a weakened peak at around $27-28^{\circ}$ and many new diffraction peaks at $23.5^{\circ}$, $30^{\circ}, 36^{\circ}, 39.5^{\circ}, 43^{\circ}, 47^{\circ}$, and $48^{\circ}$. XRD analysis was also performed on the mixed metal complexes. The Al-Ca lake $(\mathbf{F})$, and Ca-Al lake $(\mathbf{G})$ produced diffractograms which varied from lac dye; showing a strong crystalline peak at $\sim 27-28^{\circ}$ and a broad, weak peak at $41-42^{\circ}$ (Figure 5). The XRD patterns indicate the crystalline nature of the complexes. It is clear that the pattern of lac dye differs from its metal complexes or lake pigments, which may be attributed to the formation of a new, solid, crystalline structure. Presumably, this behavior is due to the coordination of metals with the electrondonating hydroxyl groups present in lac dye molecules (Kongkachuichay, Shitangkoon, Chinwongamorna et al., 2002a; Neelakantan et al., 2008).

\section{MTT cytotoxicity test}

The survival rate (\%) of cells cultured with samples of various tested concentrations (compared to the control) were tabulated in Table I. The results indicated that all samples were nontoxic to human dermal fibroblast cells over the ranges of tested concentrations $(0.78-100 \mu \mathrm{g} / \mathrm{mL})$. Surprisingly, the lac dye and the $\mathrm{Ca}$ acetate lake seemed to stimulate rather than inhibit growth of human dermal fibroblast cells. It has been previously reported that lac dye (food grade, purity $95 \%$ and above) is non-toxic at the test dose of $200 \mathrm{mg} / \mathrm{kg}$ in the diets of male rats. As it shows no sign of toxicity, it has great potential use as a natural food additive (Srivastava et al., 2103). The results obtained from this study are likely to be the first research into the human dermal fibroblast toxicity of lac dye and may indicate that lac dye and its lake pigments are potentially safe for topical use. However, to ensure their safety, further study on the toxicity of lac dyes on the dermal skin from humans is suggested.

\section{Effects of $\mathrm{pH}$ on color shade}

$5 \%$ of lac dye and its various pigments were mixed with DI water and the $\mathrm{pH}$ of the mixture was measured. Lac dye itself has a pH of 2.99 and its lake pigments have differing $\mathrm{pH}$ values, i.e., alum lake, 3.16; $\mathrm{Ca}$ acetate lake, 5.59 and Al-Ca lake, 4.71. The $\mathrm{pH}$ value of each solution was then adjusted to the range of $1-13$ by adding $1 \% \mathrm{NaOH}$ or $1 \% \mathrm{HCl}$. The color shade of lac dye and its lake pigments are displayed in Figure 6. It can be seen that, at different $\mathrm{pH}$ values, lac dye possesses a higher diversity of color shade than its lake pigments. The Al$\mathrm{Ca}$ lake seems to exhibit less alteration in color shade over a wide range of both acidic and basic $\mathrm{pH}$ values. It 


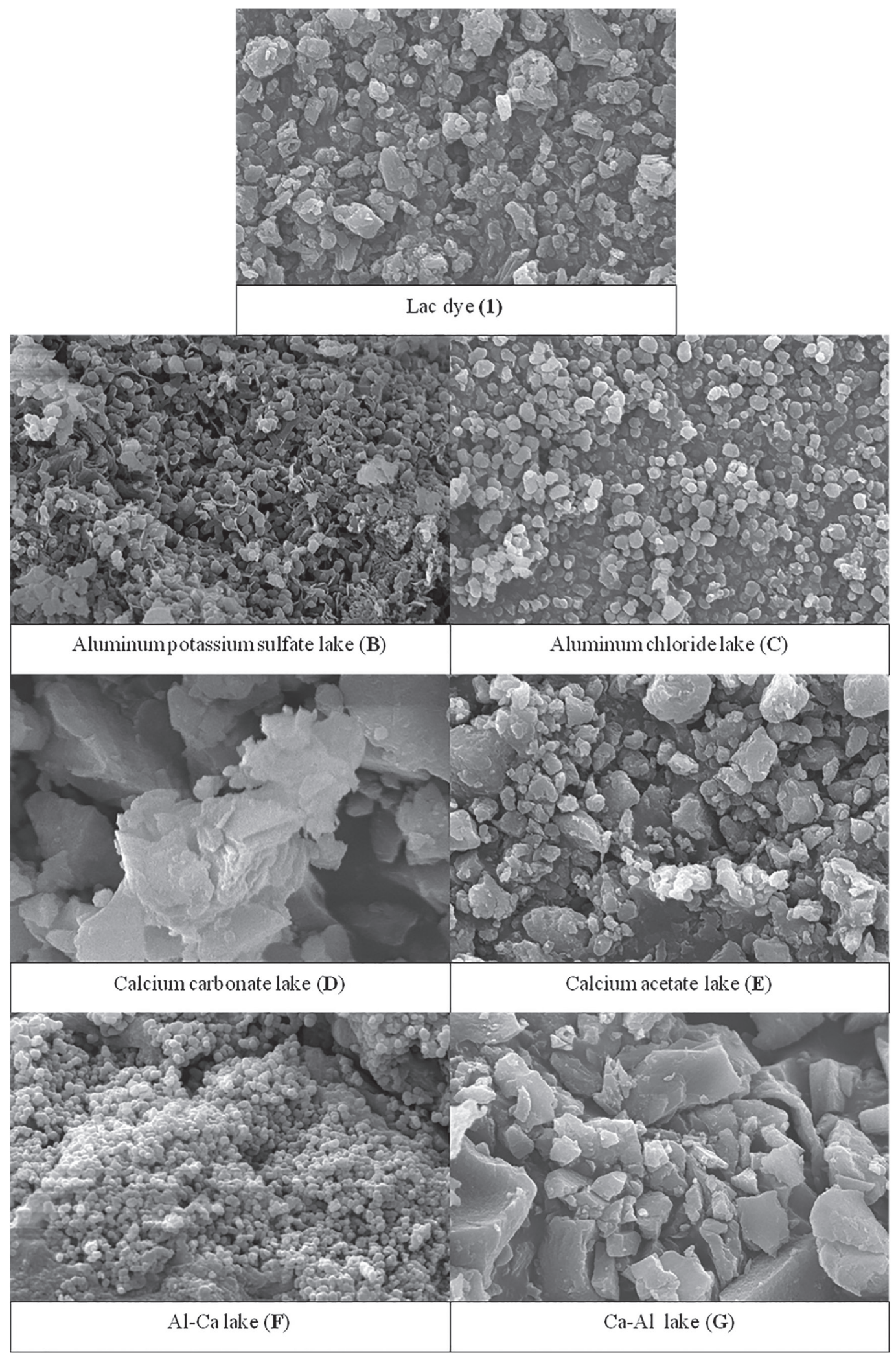

FIGURE 3 - SEM analysis of lac dye and its lake pigments.

may be concluded that lac lake pigments exhibit better stability, or greater tolerance, over extreme $\mathrm{pHs}$, than the lac dye itself.
Effects of storage on color stability

The color stability of lac dye and its lake pigments was tested under 5 conditions:ambient temperature 


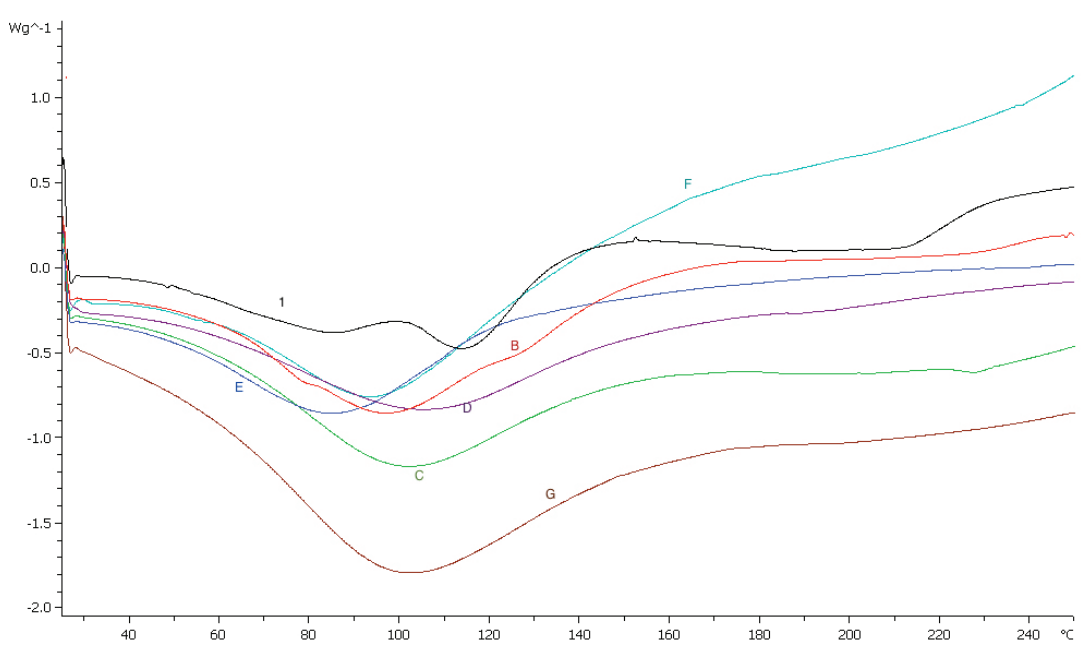

FIGURE 4 - DSC thermogram of (1) lac dye, (B) Alum lake, (C) Al chloride lake, (D) Ca carbonate lake, (E) Ca acetate lake, (F) Al-Ca lake, and (G) Ca-Al lake.
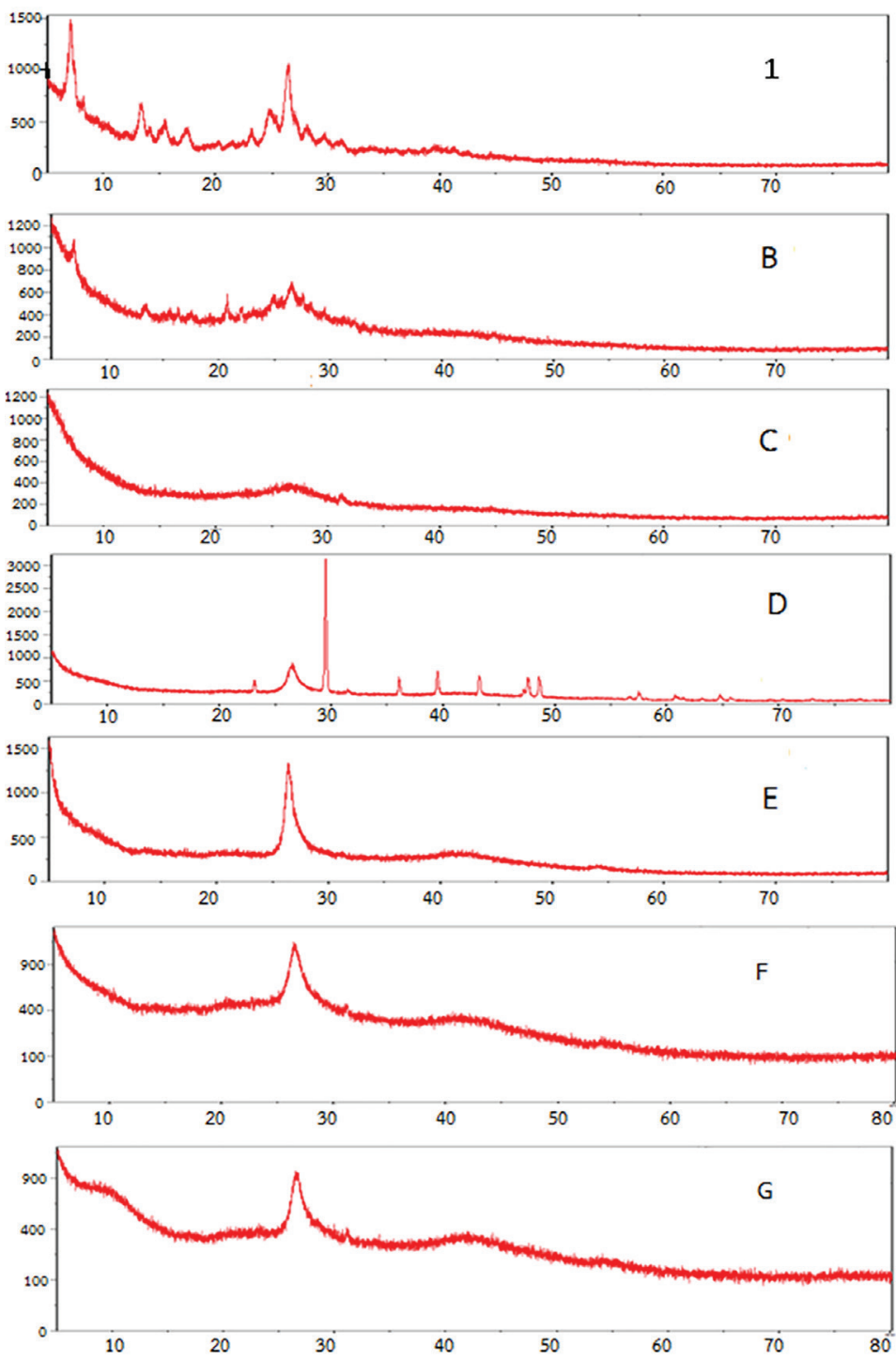

FIGURE 5 - X-ray diffractograms of (1) lac dye, (B) Alum lake, (C) Al chloride lake, (D) Ca carbonate lake, (E) Ca acetate lake, (F) Al-Ca lake, and (G) Ca-Al lake. 
TABLE I - The survival rate (\%) of human dermal fibroblast cells tested by MTT assay

\begin{tabular}{ccccc}
\hline \multirow{2}{*}{$\begin{array}{c}\text { Concentration } \\
(\boldsymbol{\mu} \mathbf{g} / \mathbf{m L})\end{array}$} & Lac dye & Alum Lake & Ca acetate lake & Ca-Al Lake \\
\cline { 2 - 4 } & $147 \pm 9$ & $98 \pm 1$ & $116 \pm 7$ & $95 \pm 5$ \\
100 & $137 \pm 2$ & $100 \pm 5$ & $113 \pm 8$ & $98 \pm 4$ \\
50 & $126 \pm 3$ & $93 \pm 3$ & $102 \pm 2$ & $94 \pm 3$ \\
25 & $109 \pm 2$ & $99 \pm 1$ & $109 \pm 2$ & $95 \pm 4$ \\
12.5 & $97 \pm 5$ & $96 \pm 3$ & $93 \pm 2$ & $96 \pm 3$ \\
6.25 & $>100$ & $>100$ & $>100$ & $>100$ \\
$\mathrm{IC}_{50}$ & & & & \\
\hline
\end{tabular}

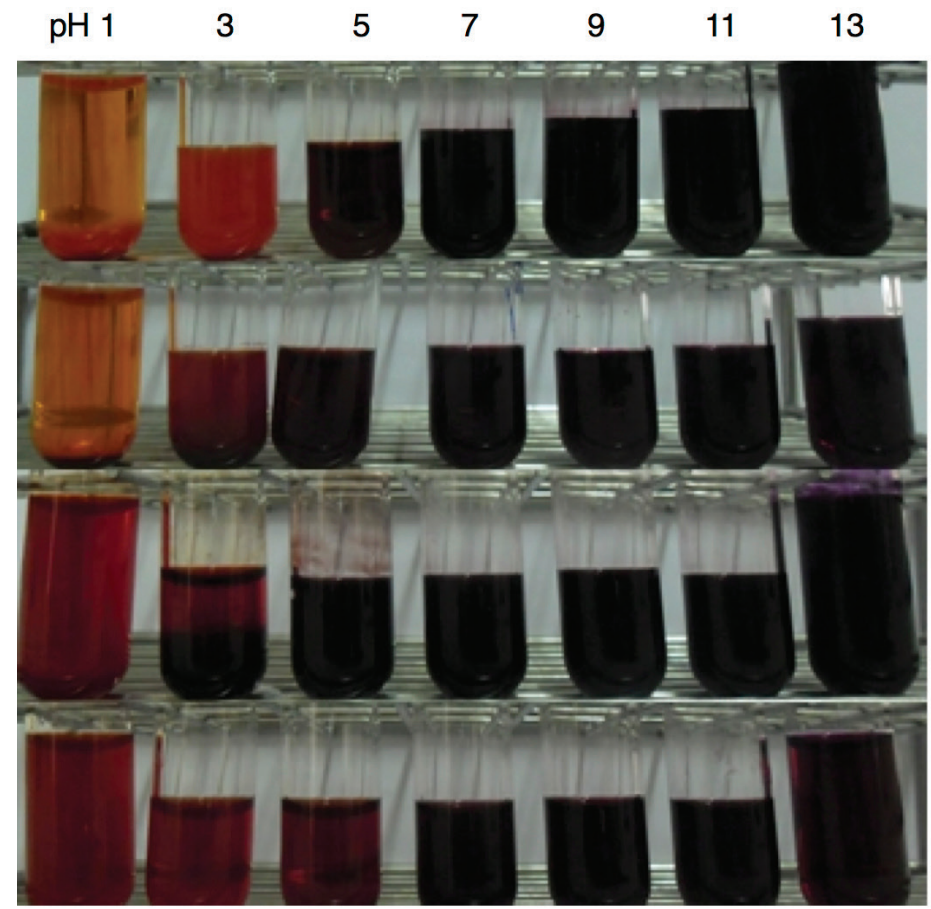

Lac dye

Alum lake

Ca acetate lake

Al-Ca lake

FIGURE 6 - Color shades of lac dye and its lake pigments at different $\mathrm{pH}$ values.

and $45{ }^{\circ} \mathrm{C}$ sunlight exposure, fluorescent exposure, and darkness. Lac dye and its pigments were tested in powder dispersions $(30 \%$ lac dye or its lake pigments in talc) and oil dispersions (45\% powder in castor oil). The color change was measured by a Chromameter. The total color difference $\left(\Delta \mathrm{E}^{*}\right)$ between week 0 and week 12 was calculated using the equation: $\Delta \mathrm{E}^{*}=\left(\Delta \mathrm{L}^{* 2}+\Delta \mathrm{a} * 2+\Delta \mathrm{b} * 2\right)^{1 / 2}$ (Gonnet, 2001). After 3 months, the lac dye itself showed more change in color than its lakes. The $\Delta \mathrm{E}^{*}$ values of lac dye are relatively higher than those of its lake pigments. In the powder dispersions, the $\Delta \mathrm{E}^{*}$ of lac dye is higher than its pigments in all conditions. The only exceptions were for those at $45^{\circ} \mathrm{C}$ in which the values were relatively close to each other (Table II). In oil paste form, the change in color of lac dye is much more visible than for lac lake pigments. It should be noted that at $45^{\circ} \mathrm{C}$, lac dye in both powder and oil dispersion forms is quite stable, as the $\Delta \mathrm{E}^{*}$ values are relatively less than for those of other storage conditions.

\section{Application of lac lakes}

Lac dye and lake pigment were used as the coloring agents in lip color product at $5.3 \%$. The formulas contain $22 \%$ cosmetic waxes, $66 \%$ cosmetic oils, $2.7 \%$ red iron oxide and $4 \% \mathrm{TiO}_{2}$. The product prepared using the lac dye produced an orange-red color while the formula containing the Al-Ca lake pigment displayed an orangebrown color (Figure 7). Both products possessed similar smooth textures but it seems that the product containing lake pigment is better in term of skin adhesion than that of lac dye. A simple test was performed to demonstrate this issue by applying the same amount of product onto a 
TABLE II - The total color difference $\left(\Delta \mathrm{E}^{*}\right)$ between week 0 and week 12 of lac dye and its lake pigments

\begin{tabular}{|c|c|c|c|c|c|c|c|c|}
\hline \multirow{3}{*}{ Condition } & \multicolumn{8}{|c|}{$\Delta \mathbf{E}^{*}$} \\
\hline & \multicolumn{2}{|c|}{ Lac dye } & \multicolumn{2}{|c|}{ Alum lake } & \multicolumn{2}{|c|}{ Ca acetate lake } & \multicolumn{2}{|c|}{ Al-Ca lake } \\
\hline & $\begin{array}{c}\text { powder } \\
\text { form }\end{array}$ & $\begin{array}{c}\text { oil paste } \\
\text { form }\end{array}$ & $\begin{array}{c}\text { powder } \\
\text { form }\end{array}$ & $\begin{array}{c}\text { oil paste } \\
\text { form }\end{array}$ & $\begin{array}{c}\text { powder } \\
\text { form }\end{array}$ & $\begin{array}{c}\text { oil paste } \\
\text { form }\end{array}$ & $\begin{array}{c}\text { powder } \\
\text { form }\end{array}$ & $\begin{array}{c}\text { oil paste } \\
\text { form }\end{array}$ \\
\hline Ambient temperature & 3.03 & 13.22 & 2.08 & 3.66 & 1.86 & 2.45 & 2.67 & 2.54 \\
\hline Sunlight & 3.46 & 13.69 & 2.28 & 3.12 & 0.52 & 1.71 & 0.93 & 1.48 \\
\hline Fluorescent & 2.96 & 12.40 & 2.80 & 3.97 & 1.45 & 0.30 & 0.90 & 0.99 \\
\hline Dark room & 4.97 & 13.50 & 2.30 & 3.59 & 1.09 & 2.03 & 1.40 & 2.56 \\
\hline $45^{\circ} \mathrm{C}$ & 1.29 & 7.43 & 0.91 & 3.49 & 2.86 & 2.42 & 1.69 & 0.71 \\
\hline
\end{tabular}

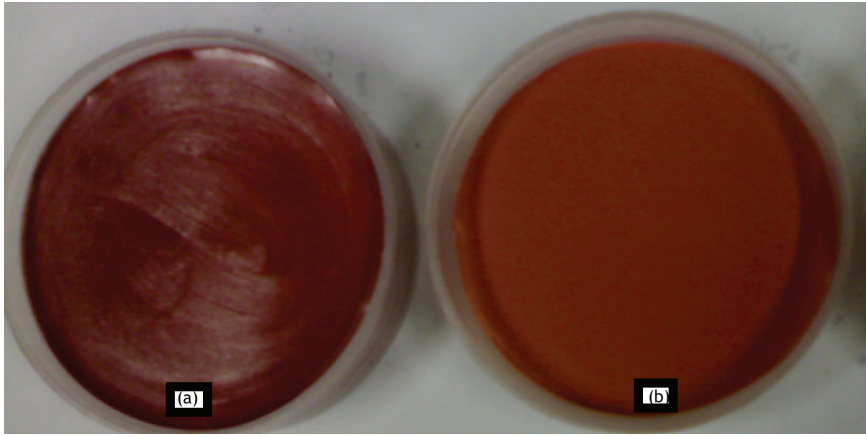

FIGURE 7 - Color shade of lip color products containing (a) Lac dye, (b) Al-Ca lake pigment.

$4 \mathrm{~cm}^{2}$ area of skin. The color was then wiped with cotton moistened with micelle cleanser. The color of the product with lac lake adhered to the skin better than that with lac dye (Figure 8).

\section{CONCLUSION}

The preparation of lac lake pigments using different $\mathrm{Al}$ and $\mathrm{Ca}$ salts resulted in pigments of varying physicochemical properties. SEM analysis demonstrated that the surface morphology of lac dye, which has characteristically fine particles, was changed after reacting with metal salts. The XRD and DSC studies indicated that the crystalline structure of lac dye was changed after coordinating with metal salts and a new solid compound was formed. The prepared lac lakes showed less alteration of color shade over acidic and basic pHs and also exhibited better color stability compared to lac dye. Lac dye and its lake pigments are not cytotoxic to human dermal skin fibroblast cells in vitro, and showed strong potential for use as cosmetic colorant.

\section{ACKNOWLEDGMENTS}

The authors are grateful to the National Research Council of Thailand (NRCT) for financial support (Grant no. 55208050010). The School of Cosmetic Science, Mae Fah Luang University is acknowledged for providing the space and facilities to conduct this study.

\section{REFFERENCES}

Abdelhedi M, Ktari L, Dammak M, Cousson A, Kolsi AW. DSC, Structural single crystal and X-ray powder diffraction study of the ammonium sulfate selenate mixed solid solution. J Alloy Compd. 2008; 460(1-2):147-151.

Anstead DF. Pigments, lakes and dyestuffs in cosmetics. J Soc Cosmet Chem. 1959;10(1):1-19.

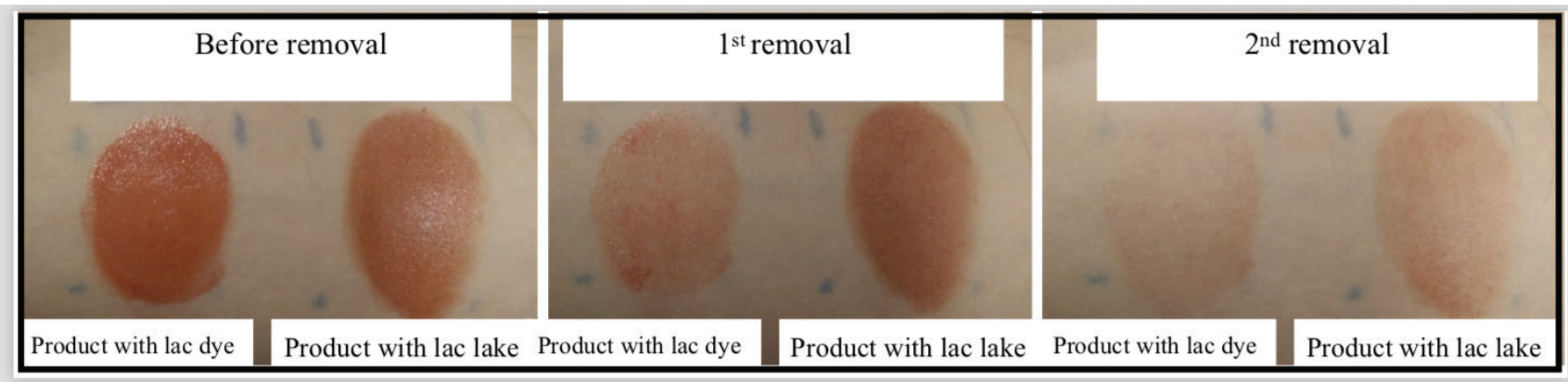

FIGURE 8 - Color adhesion of the lip color products on the skin. 
Basu SP, Haq AA, Chaudhuri SK. Preliminary study on the antibacterial activity of lac dye. 14-15 June, ILRI, Ranchi, Bihar, India. Proc Nat Seminar, Lac Industry-Challenges and Solution; 1996. p.109-112.

Burwood R, Read G, Schofield K, Wright DE. The pigments of stick lac, part I, isolation and preliminary examination. J Chem Soc C. 1965;6067-6073.

Burwood R, Read G, Schofield K, Wright DE. The pigments of stick lac, part II, the structure of laccaic acid A. J Chem Soc C. $1976 ; 842-851$.

Cosentino HM, Fontenele RS, Del Mastro NL. Stability of $\gamma$-irradiated carmine. Physica Scripta. 2005;T118:223-224.

Divya, Singh RP, Baboo B, Prasad KM. Evaluation of coloring efficacy of lac dye in comminuted meat product. J Food Sci Technol. 2011;48(3):378-381.

Erwin E. Characterization of historical organic dyestuffs by liquid chromatography-mass spectrometry. Anal Bioanal Chem. 2008;391(1):33-57.

Gonnet JF. Color effects of co-pigmentation of anthocyanin revisited-3. A further description using CIELAB differences and Chem. 2001;75(4):473-485.

Hua Z, Hong Z, Zhonghe Z. Characteristics and extraction technology of natural pigments from animals and plant. Forest Res. 2003;16(5):628-635.

Hong Z, Guigan F, Hua Z, Kun L. Determination of anthraquinone content in lac dye through combined spectrophotometry and HPCE. Procedia Engineering. 2011;18:86-94.

Jimtaisong A, Janthadee R, Nakrit T. In vitro antioxidant activities of laccaic acids and its aluminum lake. Food Sci Biotechnol. 2013;22(4):1055-1061.

Kongkachuichay P, Shitangkoon A, Chinwongamorn N. Thermodynamics of adsorption of laccaic acid on silk. Dyes Pigm. 2002a;53(2):179-185.

Kongkachuichay P, Shitangkoon A, Chinwongamorna N. Studies on dyeing of silk yarn with lac dye: Effects of mordants and dyeing conditions. Science Asia. 2002b;28:161-166.
Neelakantan MA, Marriappan SS, Dharmaraj J, Jeyakumar T, Muthukumaran K. Spectral, XRD, SEM and biological activities of transition metal complexes of polydentate ligands containing thiazole moiety. Spectrochim Acta A Mol Biomol Spectrosc. 2008;71(2):628-635.

Oka H, Ito Y, Yamada S, Kagami T, Hayakawa J, Harada K, et al. Separation of lac dye components by high-speed counter-current chromatography. J Chromatogr A. 1998;813(1):71-77.

Plumb JA, Milroy R, Kaye SB. Effects of the $\mathrm{pH}$ dependence of 3-(4,5-dimethylthiazol-2-yl)-2,5-diphenyltetrazolium bromideformazan absorption on chemosensitivity determined by a novel tetrazolium based assay. Cancer Res. 1989;49(16):4435-4440.

Schmidt-Jacobsen JF, Frandsen RS. Method for the preparation of a carminic acid lake. United States patent US 2009/0025153 A1. CHR-Hansen A/S2009.

Schmidt-Jacobsen JF, Frandsen RS. Method for the preparation of a carminic acid lake. United States patent US 7641704 B2.CHR-Hansen A/S 2010.

Smith R, Wagner S. Dyes and the environmental is natural better? Amer Dyestuff Rep. 1991;80:32-34.

Srivastava S, Ray DP, Pandey SK, Prasad KM, Prasad M, Baboo B. Pure lac dye: A potential natural food additive. Int J Emerg Technol Adv Eng. 2013;3(7):589-594.

Taeko N, Keiko M. A study of lac dyeing with tin mordant. Kaseigaku Zasshi. 1980;31:19-23.

Vera de Rosso V, Mercadante AZ. Dyes in South America. In: Bechtold T, Mussak R, editors. Handbook of natural colorants. West Sussex, UK: John Wiley and Sons; 2009. p. 53-64.

Wongsooksin K, Rattanaphani S, Tangsathitkulchai M, Rattanaphani V, Bremner JB. Study of an Al (III) complex with the plant dye brazilen from Ceasalpinia sappan Linn. Suranaree J Sci Technol. 2008;15(2):160-163.

Wongwad E, Jimtaisong A, Saewan N, Krisadaphong P. Preparation of lake pigment from Thai lac dye. Int Confer Biomed Eng Technol PCBEE. 2012;34:73-78.

Received for publication on $01^{\text {st }}$ March 2018 Accepted for publication on $12^{\text {th }}$ December 2018 